\title{
Screen viewing, body mass index, cigarette smoking and sleep duration in Belgrade University student population: results of an observational, cross-sectional study
}

\author{
IGOR PANTIC ${ }^{1}$, MILICA MALBASA ${ }^{2}$, SINISA RISTIC ${ }^{3}$, DRENKA TURJACANIN ${ }^{1}$, \\ SNEZANA MEDENICA ${ }^{3}$, JOVANA PAUNOVIC ${ }^{2}$, SENKA PANTIC ${ }^{4}$
}

'University of Belgrade, School of Medicine, Institute of Medical Physiology, Belgrade, Serbia.

University of

Belgrade, School of Medicine, Belgrade, Serbia.

${ }^{3} U$ niversity of Eastern

Sarajevo, Faculty of Medicine, Foca, Bosnia and Herzegovina.

${ }^{4}$ University of Belgrade,

School of Medicine, Institute of Histology and Embryology, Belgrade, Serbia.

Recibido el 13 de octubre de 2010, aceptado el 9 de mayo de 2011.

Corresponding: Igor Pantic, Md

University of Belgrade, School of Medicine, Institute of Medical Physiology, Visegradska 26/2, 11000, Belgrade, Serbia.

Tel: +381113607097 E-mail: igorpantic@gmail.

\begin{abstract}
Background: Subjects that spend more time working on computers or watching television could have a higher body mass index. Aim: To assess the relationship between time spent in front of a screen and studying, body mass index (BMI), smoking, and sleep duration among university students. Material and Methods: A cross-sectional study of 734 randomly selected students aged $21 \pm 2$ years (450 females) that responded an anonymous, structured questionnaire about time spent watching television or in front of a computer, time spent studying, number of daily hours of sleep, smoking habits and number of daily meals. Body mass index was also calculated for all subjects Results: Among males, the number of daily sleep hours, time spent working with computers and number of daily meals were significantly higher and time spent studying was significantly lower than females. Nonsmokers ate a significantly higher number of meals and spent less time watching television. No association was observed between time spent in front of a screen and number of sleep hours of body mass index. Conclusions: Men and smokers spend more time working in computers. There is no association between body mass index and time spent in front of screens.
\end{abstract}

(Rev Med Chile 2010; 139: 896-901).

Key words: Body mass index; Gender; Smoking; Television.

\section{Asociación entre el tiempo dedicado a actividades sedentarias e índice de masa corporal en estudiantes universitarios en Belgrado}

Antecedentes: Aquellos individuos que trabajan en computadores o ven televisión por mucho tiempo pudieran tener un indice de masa corporal mayor. Propósito: Evaluar la asociación entre el tiempo ocupado viendo televisión o trabajando en el computador, indice de masa corporal, hábito de fumar y horas diarias de sueño en estudiantes universitarios. Material y Métodos: Se efectuó un estudio transversal de 734 estudiantes elegidos al azar de $21 \pm 2$ años de edad (450 mujeres), que respondieron una encuesta acerca del número de horas que pasaban viendo televisión, trabajando en un computator o estudiando, el número de horas diarias de sueño, hábito tabáquico y número diario de comidas. Además se calculó el índice de masa corporal de los encuestados. Resultados: Los hombres dormían más horas por día, pasaban más tiempo trabajando en computadores o viendo televisión y estudiaban menos horas por día que las mujeres. Los no fumadores comían más comidas por día y permanecian menos horas viendo televisión. No hubo una asociación significativa 
Behavioral characteristics in Belgrade student population - I. Pantic et al

entre el número de horas enfrente de una pantalla o la cantidad de horas diarias de sueño con el indice de masa corporal. Conclusiones: Los hombres y los fumadores pasan más tiempo viendo televisión o trabajando en computadores. No se observó una relación entre el tiempo que se permanece frente a una pantalla y el indice de masa corporal.

T $\mathrm{n}$ the past decade, several studies indicated that screen-viewing behaviors (TV viewing, computer use) may be connected with increased body weight in children and adolescents ${ }^{1,2}$. In some European countries, after-school TV viewing is part of the home culture with children and adolescents spending more than 2 hours on TV after school, and more than 1 hour on computer use per day, predominantly computer games ${ }^{3}$. Also, some researchers in Germany have recently found statistically significant positive correlations between body mass index (BMI) and school marks, as well as between some nutritional habits and school marks in secondary school pupils ${ }^{4}$. The same study also indicated that there is a negative correlation between TV/PC viewing and educational results in the same population sample (729 students).

Social networking sites, MySpace and Facebook, are today becoming increasingly popular especially among young people. The impact of time spent on online social networking on various health indicators, including BMI, food intake, and sleep has not yet been investigated.

The relationships between time spent on TV, obesity, gender, food intake habits, and sleep duration, remain controversial. A paper published in 2010 revealed that in European children, TV viewing and male gender are significant positive predictors for fast-food, sugar sweetened beverages and pastry pattern, while longer sleeping duration is positively associated with dietary patterns that include fruit and vegetables ${ }^{5}$.

Although recent epidemiological data has shown that cigarette smoking rate in European adolescents started to decrease since the year $2000^{6}$, tobacco use still remains a major health issue. Apart from negative effects on respiratory and cardiovascular systems, nicotine and other tobacco-related substances significantly change various metabolic reactions in central nervous system, thereby affecting human behavior, concentration, sleep and nutritional habits ${ }^{7,11}$. Nicotine receptors are primarily found in presynaptic membranes affecting release of several neurotransmitters, such as acetylcholine, dopamine, serotonin, and norepinephrine $^{12}$. It has been suggested that nicotine receptors may have an important role in sleep/ wake cycle. Some author state that nicotine receptor stimulation promotes wake time, and reduces total sleep time and rapid eye movement sleep $(\text { REMS })^{12}$. On the other hand many other studies conducted in order to investigate the influence of cholinergic agonists in sleep produced mixed and inconclusive results ${ }^{13}$.

Having in mind the findings of other authors, we considered of scientific importance to investigate the relationships between times spent on screen viewing and studying, BMI, smoking, and sleep duration in 24 hour period in a university student sample population.

\section{Subjects and Methods}

An observational, population-based, multisite, cross-sectional epidemiologic study was conducted during 2009/10 school year, at The University of Belgrade. The study sample was determined based on 95\% confidence interval for the Belgrade university student population (base population). A total of 752 out of 796 students agreed to participate in the study (94.47\% of those invited), and were interviewed using an anonymous, structured questionnaire. A pilot phase preceded the current study to test the feasibility of the questionnaire and to train the interviewer. In order to make the sample representative for the whole University of Belgrade student population, our study included the students from several faculties of The University of Belgrade (The Faculty of Law, Faculty of Medicine and Technical Faculties).

All students received and completed the questionnaire approximately at the same time of the 2009/10 school year, during the summer term, on average 3 months before the main exam periods at their Faculties.

Data of height and weight were obtained for all subjects and BMI $\left(\mathrm{kg} / \mathrm{m}^{2}\right)$ was calculated from the 
baseline measures of body weight and height. BMI ranging from 18.5 to 25 indicated optimal weight; a BMI lower than 18.5 suggests that the person is underweight, students with BMI above 25 were considered to be overweight ${ }^{14,15}$. BMI above 30 indicated obesity. Data was also collected on gender, average daily time spent on screen viewing (TV, PC, social networks, $\mathrm{PC}$ for other uses except social networking, separately, and together), average time spent on studying, sleep duration during 24-hour period, tobacco use (current smoking status), average number of meals per day. All data was collected following established protocols described in previous studies ${ }^{16-19}$. Upon return, questionnaires were screened for complete responses to several key items, and the incomplete responses were excluded from the study. As a result, 734 subject sample was obtained ( $97.6 \%$ of those who agreed to participate in the research), and was statistically described and analyzed. Average age of the subjects was 20.9 years $(\mathrm{SD}=1.97$ years). 450 subjects were female $(61.3 \%$, average age 20.8 years, $\mathrm{SD}=$ 1.9 years), and 284 subjects $(38.7 \%)$ were male (average age 21.1 years, $\mathrm{SD}=2.1$ years). Subjects excluded from the study did not statistically differ from study sample in gender distribution and age ( $p>0.05$, Pearson's chi-square test).

During the administration of the questionnaire, the students were informed about the objective of the study. The study protocol was in accordance with the guidelines of the Helsinki Declaration 1975, revised in 1983, and the guidelines of Ethical Committee of The School of Medicine, University of Belgrade.
Statistical data analysis was done using SPSS v 10.1 statistical package (SPSS Inc., Chicago, IL), and GraphPad statistical software (GraphPad Software, Inc. La Jolla, CA). Simple descriptive statistics was calculated and reported as percentages, means, and standard deviations. Analysis was done using Student's t-test, Pearson product-moment correlation coefficient. Mann-Whitney U test and Spearman's rank correlation coefficient were also used for nonparametric data, and parametric data where coefficient of variation was higher than $30 \%$. Value $\mathrm{p}<0.05$ was considered statistically significant, and $\mathrm{p}<0.01$ was considered to be statistically highly significant.

\section{Results}

Average daily time spent on screen viewing (TV, PC, social networks, PC for other uses except social networking, separately, and together), BMI, sleep duration during 24-hour period, tobacco use, average number of meals per day, in male and female subjects, as well as the whole study sample, along with standard deviations is shown on Table 1.

$92(12.53 \%)$ students were considered overweight and 12 students $(1.63 \%)$ were obese (BMI > 30). BMI in male students was higher than in females, and the difference was highly statistically significant $(\mathrm{p}<0.001)$.

$67.3 \%$ of the students used social networking sites $(70.89 \%$ female, $61.97 \%$ male).

Statistically significant differences between

Table 1. BMI, sleep duration (hours), studying, screen viewing, average number of meals per day, in male and female subjects, and in the whole study sample

\begin{tabular}{|c|c|c|c|}
\hline & Female & Male & Total \\
\hline BMI & $20.42 \pm 2.1^{* *}$ & $24.15 \pm 3.14^{* *}$ & $21.86 \pm 3.14$ \\
\hline Sleep duration (h) & $7.452 \pm 1.367^{*}$ & $7.658 \pm 1.269^{*}$ & $7.532 \pm 1.333$ \\
\hline Time spent on studying (h) & $4.79 \pm 2.38^{*}$ & $4.38 \pm 1.91^{*}$ & $4.63 \pm 2.22$ \\
\hline Average time spent on TV (h) & $2.07 \pm 1.85$ & $2.13 \pm 1.56$ & $2.09 \pm 1.74$ \\
\hline Average time spent on social networking sites (h) & $1.25 \pm 1.34^{* *}$ & $0.96 \pm 1.01 * *$ & $1.14 \pm 1.23$ \\
\hline Average time spent on PC without social networking $(h)$ & $1.16 \pm 1.20^{* *}$ & $1.65 \pm 2.18^{* *}$ & $1.35 \pm 1.68$ \\
\hline Total average time spent on PC (h) & $2.17 \pm 1.92$ & $2.41 \pm 2.43$ & $2.26 \pm 2.13$ \\
\hline Average daily number of meals & $2.94 \pm 0.92 * *$ & $3.24 \pm 1.01 * *$ & $3.06 \pm 0.96$ \\
\hline
\end{tabular}


Behavioral characteristics in Belgrade student population - I. Pantic et al

Table 2. BMI, sleep duration (hours), studying, screen viewing, average number of meals per day in smokers and non-smokers.

\begin{tabular}{|lll|}
\hline & Smokers & Non-Smokers \\
\hline Gender & $28.57 \%$ male, $71.43 \%$ female & $40.65 \%$ male, 59.35\% female \\
\hline BMI & $21.48 \pm 3.08$ & $21.90 \pm 3.27$ \\
\hline Sleep duration $(h)$ & $7.27 \pm 1.49 *$ & $7.58 \pm 1.29^{*}$ \\
\hline Time spent on studying (h) & $4.27 \pm 2.13$ & $4.79 \pm 2.95$ \\
\hline Average time spent on TV (h) & $2.50 \pm 1.98^{*}$ & $2.02 \pm 1.68^{*}$ \\
\hline Average time spent on social networking sites (h) & $1.43 \pm 1.21^{* *}$ & $1.08 \pm 1.23^{* *}$ \\
\hline Average time spent on PC without social networking (h) & $1.40 \pm 1.68$ & $1.34 \pm 1.68$ \\
\hline Total average time spent on PC $(h)$ & $2.60 \pm 2.27$ & $2.20 \pm 2.09$ \\
\hline Average daily number of meals $(h)$ & $2.79 \pm 0.91 * *$ & $3.11 \pm 0.96^{* *}$ \\
\hline
\end{tabular}

${ }^{*} p<0.05 ;{ }^{* *} p<0.01$

male and female students were detected in sleep duration $(\mathrm{p}<0.05)$, average number of meals per day $(\mathrm{p}<0.01)$, time spent on studying $(\mathrm{p}<0.05)$, and average time spent on social networking $(\mathrm{p}<0.01)$.

$16.21 \%$ of the students were smokers. Table 2 shows average BMI, sleep duration, average daily time spent on screen viewing, average number of meals in smokers and non-smoking part of the sample. Daily sleep duration among smokers was statistically higher than in non-smoking students $(\mathrm{p}<0.05)$. Also, average time spent on TV, and daily time spent on social networking sites were higher in smokers than in non-smokers $(\mathrm{p}<0.05$ and $\mathrm{p}<0.01$, respectively). Non-smokers had higher daily number of meals $(\mathrm{p}<0.01)$.

Age of the students was not statistically correlated to screen viewing (TV, PC, social networking), sleep duration, and daily number of meals $(p>0.05)$. Smokers and non-smokers did not statistically differ in age ( $\mathrm{p}>0.05)$.

There were no statistically significant differences (Chi square test and analysis of varianceANOVA, respectively, $p>0.05$ ) between different career choices in age, smoking time spent on screen viewing (TV, PC, social networking), and daily number of meals. This result could indicate that the sample as a whole was relatively homogenous.

No statistically significant correlation was found between screen viewing behaviors and BMI ( $p>0.05)$. Also there was no correlation between sleep duration and screen viewing activities $(\mathrm{p}>0.05)$.

\section{Discussion}

Most studies that address screen viewing and food intake behaviors have so far been carried out in high-income countries, while in developing countries, this issue has not been the focus of such studies and, as a result, there is a lack of data about $\mathrm{it}^{20}$. This is especially true for the West Balkan region that has a specific socioeconomic environment.

Our study suggests that the gender is related to online behaviors. This is in accordance with the findings of other authors that male subjects are in some circumstances likely to spend more time on screen-viewing than females ${ }^{21}$.

The lack of correlation between screen viewing and $\mathrm{BMI}$, indicates that TV and personal computer use, are not significant factors affecting body mass in student population in Belgrade. However, it is known that average body mass and BMI in one population are complex variables that depend on many factors, such as local economy, customs, religious views, average household budget, national food and nutrition policy, implementation of certain public health interventions etc ${ }^{22}$. Having this in mind, our study could be a good basis for further research of population obesity-related factors in this part of Europe.

Effects of smoking on sleep duration and vice versa, have so far been subject of many preclinical and clinical investigations ${ }^{23,26}$. However, in the past 20 years, there have been very few epidemiological data regarding this issue done on large, young, age- 
homogenous population. Our results are in accordance with other author findings that nicotine consumption influences sleeping habits, primarily by reducing sleep duration. Moreover, our findings suggest that cigarette smoking might be related to various other behavioral characteristics, such as screen viewing, and nutritional habits. Still, it is difficult to draw definite conclusions about the existence and level of this relationship. A larger study, with a more detailed questionnaire, examining not only the smoking status of a student, but also the actual dose of nicotine (number of cigarettes per day), and smoking history, could enable us to confirm this assumption.

The cross-sectional design of this study was also its main limitation. Prospective cohort would perhaps be more scientifically valuable, due to its ability to recognize the causal relationship between various variables. In goes without saying that in the future, it would be very interesting to see the results of the similar study where a prospective design has been implemented. Also, sample size of 734 students may have limited the ability to detect a significant interaction between some of the factors in correlation / regression analysis.

Some authors believe that, although the relationship between screen viewing and BMI is complex and inconsistent across racial/ethnic subgroups, health workers should continue to recommend limiting screen-related behaviors when counseling young people on healthy habits, knowing that screen viewing is a modifiable behavioral factor, whereas other factors associated with BMI (for example, socioeconomic status) are less quickly and easily changed ${ }^{27}$. These remarks are in accordance with conclusions of our previous studies $^{28}$ (and unpublished observations). Our opinion is also, that, regardless of the complexity of a relationship between screen viewing and obesity, proper nutritional/life style public health policy should be implemented in order to preserve/change certain behavioral aspects of adolescent population.

Acknowledgement: The authors are grateful to the Ministry of Education and Science, Republic of Serbia, Research Projects OI-175059 and III41027.

\section{References}

1. Fulton JE, Wang X, Yore MM, Carlson SA, Galuska DA, Caspersen CJ. Television viewing, computer use, and BMI among U.S. children and adolescents. J Phys Act Health 2009; 6 Suppl 1: S28-35.

2. Aucote HM, Cooper A. Relationships between body fatness, small-screen sedentary activity and regionality among schoolchildren in Victoria, Australia. Aust J Rural Health 2009; 17 (3): 141-6.

3. Jago R, Page A, Froberg K, Sardinha LB, KlassonHeggebø L, Andersen LB. Screen-viewing and the home TV environment: the European Youth Heart Study. Prev Med 2008; 47 (5): 525-9.

4. Neumann H, Neumann P. Nutrition and exercise of schoolchildren. Results of a cross-sectional study at the Lessing Gymnasium (secondary) school in Mannheim, Germany. Dtsch Med Wochenschr 2007; 132 (51-52): 2736-42.

5. Moreira P, Santos S, Padrão P, Cordeiro T, Bessa M, Valente $\mathrm{H}$, et al. Food patterns according to sociodemographics, physical activity, sleeping and obesity in Portuguese children. Int J Environ Res Public Health 2010; 7 (3): 1121-38.

6. Beck F, Legleye S. Sociology and epidemiology of consumption of psychoactive substances in adolescents. Encephale 2009; 35 Suppl 6: S190-201.

7. Romero MI, Santander J, Hitschfeld MJ, Labbé M, Zamora V. [Smoking and alcohol drinking among medical students at the Pontificia Universidad Católica de Chile]. Rev Med Chile 2009; 137 (3): 361-8.

8. Horwitz ZB. Consumo de alcohol y tabaco en estudiantes de medicina. Rev Med Chile 2009; 137 (10): 1400-1.

9. Puschel K, Thompson B, Olcay F, Ferreccio C. [Predictive factors for smoking initiation and quitting among a cohort of Chilean women followed for 5.5 years]. Rev Med Chile 2009; 137 (8): 1001-9.

10. Chamorro SG. [Fighting the coronary artery disease epidemic in Chile: caveats in the control of cardiovascular risk factors]. Rev Med Chile 2008; 136 (5): 551-4.

11. Rodríguez J, Fernández AM, Hernández E, Valdés M, Villalón M, Ramírez S, et al. [Prevalence of drug abuse among children in basic schools]. Rev Med Chile 2009; 137 (6): 774-84.

12. Salín-Pascual RJ, Alcocer-Castillejos NV, Alejo-Galarza G. Nicotine dependence and psychiatric disorders. Rev Invest Clin 2003; 55 (6): 677-93.

13. Page F, Coleman G, Conduit R. The effect of transdermal nicotine patches on sleep and dreams. Physiol Behav 
2006; 88 (4-5): 425-32.

14. Aronne LJ. Classification of obesity and assessment of obesity-related health risks. Obes Res 2002; 10 Suppl 2: 105S-15S.

15. Pedro MR, Barba CV. Nutritional issues and status of older persons of the Philippines: the IUNS, CRONOS and other studies. J Nutr Health Aging 2001; 5 (2): 92-6.

16. Kimm SY, Obarzanek E, Barton BA, Aston CE, Similo SL, Morrison JA, et al. Race, socioeconomic status, and obesity in 9- to 10-year old girls: the NHLBI Growth and Health Study. Ann Epidemiol 1996; 6 (4): 266-75.

17. Sugiyama T, Salmon J, Dunstan DW, Bauman AE, Owen N. Neighborhood walkability and TV viewing time among Australian adults. Am J Prev Med 2007; 33 (6): 444-9

18. Von Laer Tschudin L, Chattopadhyay C, Pandit S, Schramm-Garaj K, Seth U, Debnath PK, et al. Risk factors for under- and overweight in school children of a low income area in Kolkata, India. Clin Nutr 2009; 28 (5): 538-42.

19. Chang G, Sherritt L, Knight JR. Adolescent cigarette smoking and mental health symptoms. J Adolesc Health 2005; 36 (6): 517-22.

20. Fernandes RA, Christofaro DG, Casonato J, Costa Rosa CS, Costa FF, Freitas Júnior IF, et al. Leisure time behaviors: prevalence, correlates and associations with overweight in Brazilian adults. A cross-sectional analysis. Rev Med Chile 2010; 138 (1): 29-35.

21. Hoyos Cillero I, Jago R, Sebire S. Individual and social predictors of screen-viewing among Spanish school children. Eur J Pediatr 2011; 170 (1): 93-102.

22. Antoni Antoni-Degac K, Kamenski M, Kati D, Butigan M, Laido Z, Kai-Rak A, et al. Using of household budget survey data for public health monitoring of dietary habits in Croatia-DAFNE initiative. Acta Med Croatica 2010; 64 (1): 17-24.

23. Hamidovic A, de Wit H. Sleep deprivation increases cigarette smoking. Pharmacol Biochem Behav 2009; 93 (3): 263-9.

24. Parrott AC. Stress modulation over the day in cigarette smokers. Addiction 1995; 90 (2): 233-44.

25. Tamaki T, Kaneita Y, Ohida T, Yokoyama E, Osaki Y, Kanda $\mathrm{H}$, et al. Prevalence of and factors associated with smoking among Japanese medical students. J Epidemiol 2010; 20 (4): 339-45.

26. Jähne A, Cohrs S, Rodenbeck A, Andreas S, Loessl B, Feige $B$, et al. Nicotine. Influence on sleep and its relevance for psychiatry and psychotherapy. Nervenarzt 2010; 81 (7): 844-59.

27. Richmond TK, Walls CE, Gooding HC, Field AE. Television viewing is not predictive of BMI in Black and Hispanic young adult females. Obesity (Silver Spring). 2010; 18 (5): 1015-20.

28. Pantic I, Turjacanin D, Ristic S, Medenica S. Enormous part of free time spent on television viewing and computer use in an age homogenous group of primary school children. Psychiatr Danub 2010; 22: accepted for press. 